\title{
Antioxidant and hepatoprotective potential of Lawsonia inermis L. leaves against 2-acetylaminofluorene induced hepatic damage in male Wistar rats
}

\author{
Manish Kumar ${ }^{1}$, Paramjeet Kaur ${ }^{1}$, Madhu Chandel ${ }^{1}$, Amrit Pal Singh ${ }^{2}$, Arpana Jain ${ }^{3}$ and Satwinderjeet Kaur ${ }^{1 *}$
}

\begin{abstract}
Background: Lawsonia inermis (Lythraceae) is an ethnomedicinal plant, traditionally known for curing several ailments such as skin diseases, bacterial infections, jaundice, renal lithiases and inflammation etc. The present work deals with assessment of in vitro antioxidant and in vivo hepatoprotective potential of butanolic fraction (But-LI) of Lawsonia inermis L. leaves.

Methods: Antioxidant activity was evaluated using deoxyribose degradation, lipid peroxidation inhibition and ferric reducing antioxidant power (FRAP) assay. In vivo protective potential of But-LI was assessed at 3 doses [100, 200 \& $400 \mathrm{mg} / \mathrm{kg}$ body weight (bw)] against 2-acetylaminofluorene (2-AAF) induced hepatic damage in male Wistar rats.

Results: But-LI effectively scavenged hydroxyl radicals in deoxyribose degradation assay $\left(I_{50} 149.12 \mu \mathrm{g} / \mathrm{ml}\right)$. Fraction also inhibited lipid peroxidation and demonstrated appreciable reducing potential in FRAP assay. Treatment of animals with 2-AAF resulted in increased hepatic parameters such as SGOT (2.22 fold), SGPT (1.72 fold), ALP (5.68 fold) and lipid peroxidation (2.94 fold). Different concentration of But-LI demonstrated pronounced protective effects via decreasing levels of SGOT, SGPT, ALP and lipid peroxidation altered by 2-AAF treatment. But-LI administration also restored the normal liver architecture as evident from histopathological studies.

Conclusions: The present experimental findings revealed that phytoconstituents of Lawsonia inermis $L$. possess potential to effectively protect rats from the 2-AAF induced hepatic damage in vivo possibly by inhibition of reactive oxygen species and lipid peroxidation.
\end{abstract}

Keywords: Lawsonia inermis, 2-acetylaminofluorene, Lipid peroxidation, Hepatic damage, Hepatoprotective

\section{Background}

Mutations resulting spontaneously or from environmental exposure may lead to cancer [1]. Chemical bonds in DNA molecule abide same laws likewise other chemicals existing at $37{ }^{\circ} \mathrm{C}$ in aqueous environment of cell. Likewise other molecules, existence of DNA also depends upon formation and breaking of bonds. So, it is not astonishing that DNA regularly endures various kinds of chemical damages due to spontaneous thermal effects and as result of attack of other reactive molecules [2]. Various physical

\footnotetext{
* Correspondence: sjkaur2011@gmail.com; sjkaur@rediffmail.com ${ }^{1}$ Department of Botanical and Environmental Sciences, Guru Nanak Dev University, Amritsar 143005, Punjab, India

Full list of author information is available at the end of the article
}

and chemical agents (exogenous agents) causes damage to DNA, many of them are now documented as environmental carcinogens $[2,3]$. Studies have shown that chemicals play an important role in the etiology of several kinds of human cancers $[4,5]$. It is well-known that exposure to various hazardous chemicals occurs at very low doses, extends through longer time period of life and influence great part of population [6]. Tumor induction in workers exposed to coal tar in 1775 was the earliest known instance of environmental carcinogenesis documented. This very example of environmental carcinogenesis, later led to identification of various polycyclic hydrocarbons in coal tar. This also led to the finding of polycyclic hydrocarbons as skin carcinogens 
in laboratory animals. Other example was bladder carcinogenesis incidence among the workers working in the rubber and chemical industries. This led to the recognition of 2-naphthylamine as bladder carcinogen [2]. With advancement in the science, it is now well known that some of cancers are environmental in origin and can be related directly to different chemical exposures [7]. Humans are constantly exposed to plethora of xenobiotic chemicals and other related environmental pollutants which are hazardous to the health [8].

Liver is the main seat of xenobiotic metabolism and also carries out various functions in biotransformation including amino acid metabolism, lipid metabolism etc. [9-12]. Liver cancer is one of the most common malignancies occurring all over the world particularly in Asian and African countries [13]. Various risk factors linked with liver cancer are alcohol, food additives, aflatoxins, toxic chemicals from industries, pollutants etc. [14, 15]. More than 600 chemicals have been identified which can cause liver injury [16, 17]. 2-acetylaminofluorene (2-AAF) is one of the most studied chemical as model hepatocarcinogen. It was initially made as an insecticide, however its use was stopped because of its carcinogenic nature. It is an aromatic compound having solubility in organic solvents and remains insoluble in water [18-21]. 2-AAF induces its carcinogenic effects through metabolic activation via the mixed function oxidase system. Activation of 2-AAF leads to the formation of reactive electrophilic forms which react to form DNA adducts [22-24].

Nowadays, use of herbal medicines for curing variety of ailments is gaining popularity including liver diseases [25]. Number of reports are available in the literature which have shown hepatoprotective effects of natural plant products against various genotoxins, carcinogens and toxic substances including carbon tetrachloride $\left(\mathrm{CCl}_{4}\right)$, paracetamol, 2-acetylaminofluorene (2-AAF), 7, 12-dimethylbenz(a)anthracene (DMBA), thioacetamide etc. [26-34]. Lawsonia inermis L. (L. inermis) commonly known as Henna or Mehandi belongs to family Lythraceae. Traditionally, the plant is known for its medicinal properties for the cure of renal lithiases, jaundice, to heal wounds, prevent skin inflammation etc. [35-38]. It is also used by some Nigerian tribes as a therapy against poliomyelitis and measles [39]. L. inermis was reported to contain various phytoconstituents such as chlorogenic acid, ferulic acid, isoferulic acid, gallic acid, o-coumaric acid, m-coumaric acid, myricetin, naringenin-7-o-rutinoside, quercetin, $(+)$-catechin, $(-)$-catechin gallate, $(-)$-epicatechin gallate, vitexin-2'o-rhamnoside etc. [40]. Hsouna et al. [41] reported phytoconstituents $v i z$. lawsoniaside, lalioside, luteolin-7- O- $\beta$ -D-glucopyranoside, 2,4,6-trihydroxyacetophenone-2-O$\beta$-D-glucopyranoside, 1,2,4-trihydroxynaphthalene-1-
O- $\beta$-D-glucopyranoside from $L$. inermis leaves. $L$. inermis showed numerous medicinal properties viz. antimutagenic, anticlastogenic, analgesic, anti-inflammatory, antipyretic activities etc. [42-44]. Phytoconstituents from $L$. inermis leaves were reported to possess immunomodulatory activity [45]. Kaur et al. [46] carried out toxicity studies on ethanolic extract of $L$. inermis leaves using albino Wistar rats and reported that administration of rats with $80 \%$ ethanolic extract posed no toxicity in the tissues of the organs up to dose of $500 \mathrm{mg} / \mathrm{kg}$ bw. Another study by Alferah [47] reported that administration of $L$. inermis leaf solution $(200 \mathrm{mg} / \mathrm{kg} /$ day $)$ to the rats for 42 days did not induce any toxicity in liver, kidney and spleen tissue sections. Selvanayaki and Ananthi [48] reported hepatoprotective effects of aqueous extract of $L$. inermis against paracetamol induced hepatic damage in male Albino rats. Hossain et al. [49] studied hepatoprotective activity of $L$. inermis leaves against carbon tetrachloride induced liver damage in Wistar albino rats. Dasgupta et al. [50] reported anticarcinogenic activity of Henna leaves against benzo(a)pyrene induced forestomach as well as against 7,12 dimethylbenz(a)anthracene (DMBA)-initiated and croton oilpromoted skin papillomagenesis. In our previous reports [51, 52], we reported extract/fractions of $L$. inermis with antioxidant, antiproliferative and apoptosis inducing activity. Since But-LI fraction was found to exhibit high antioxidant activity and is rich in various polyphenolic phytoconstituents viz. gallic acid, catechin, chlorogenic acid, ellagic acid, kaempferol etc. [51], so we planned to investigate But-LI fraction from Lawsonia inermis L. for modulatory effects against the toxicity induced by 2 -acetylaminofluorene (2-AAF) in male Wistar rats by assessing various serum and liver tissue parameters.

\section{Methods \\ Chemicals}

2,4,6-tripyridyl-s-triazine (TPTZ), Malondialdehyde (MDA), Deoxyribose, 2-acetylaminofluorene (2-AAF) were purchased from Sigma Chemical Co. (St Louis, MO, USA). Ascorbic acid and Sodium dodecyl sulfate (SDS) were purchased from Hi-Media, Mumbai, India. All other chemicals used in the present experimental study were of AR grade.

\section{Collection of plant material and preparation of But-LI fraction}

The plant material was purchased from local market (Majeeth mandi, Amritsar), identified and authenticated by Dr. A. S. Soodan, Assoc. Prof., Department of Botanical and Environmental Sciences, Guru Nanak Dev University, Amritsar. The voucher specimen (no. 6773) has been kept in the Herbarium of the Department. Leaves were washed to ensure that they become free from any kind of dirt as 
well as other foreign particles and dried in shade. Leaves (3 $\mathrm{kg}$ ) were grounded to fine powder and extracted at room temperature to obtain butanolic fraction (But-LI) as described in Kumar et al. [51].

\section{In vitro antioxidant assays}

\section{Deoxyribose degradation assay}

Deoxyribose degradation assay was carried out by the method of Halliwell et al. [53] and Arouma et al. [54] with slight modifications. In this assay, EDTA (1 mM), $\mathrm{FeCl}_{3}(10 \mathrm{mM})$, hydrogen peroxide $(10 \mathrm{mM})$, 2-deoxyribose $(10 \mathrm{mM})$, test sample $(1 \mathrm{ml})$, phosphate buffer and Ascorbic acid $(1 \mathrm{mM})$ were mixed in the test tubes and the contents of reaction mixture were incubated at $37{ }^{\circ} \mathrm{C}$ for $1 \mathrm{~h}$. After incubation, $1 \mathrm{ml}$ of above mixture was taken and mixed with $1 \mathrm{ml}$ of 2-thiobarbituric acid (TBA) and tricholoacetic acid (TCA) each. Finally reaction mixture was heated at $80{ }^{\circ} \mathrm{C}$ on water bath for $1.5 \mathrm{~h}$. Final absorbance of the pink chromogen formed was taken spectrophotometrically at $532 \mathrm{~nm}$ using Elisa reader. Rutin was used as antioxidant standard.

Percent hydroxyl radical scavenging potential was calculated by formula as given below:

$$
\text { Radical scavenging activity }(\%)=\mathrm{A}_{0}-\mathrm{A}_{1} / \mathrm{A}_{0} \times 100
$$

where,

$A_{0}$ is the absorbance of reaction mixture + vehicle solvent,

$A_{1}$ is the absorbance of reaction mixture + test sample.

\section{Lipid peroxidation inhibition assay}

A modified thiobarbituric acid reactive species (TBARS) assay [55] was performed to determine the lipid peroxides produced using egg yolk homogenate as lipid rich media [56]. Various concentrations of test sample were added to the test tubes containing egg homogenate $(0.5 \mathrm{ml}$ of $10 \% \mathrm{v} / \mathrm{v})$. About $50 \mu \mathrm{l}$ of $\mathrm{FeSO}_{4}$ solution was added to the test tubes to induce lipid peroxidation and incubated test tubes at $37{ }^{\circ} \mathrm{C}$ for $30 \mathrm{~min}$. After $1 / 2$ hour, 20\% acetic acid ( $\mathrm{pH} 3.5), 0.8 \%$ of TBA in $1.1 \%$ SDS and TCA (20\%) were added. All the contents of the tubes were mixed properly and heated at $95^{\circ} \mathrm{C}$ for $1 \mathrm{~h}$. After heating, test tubes were cooled, followed by addition of $5 \mathrm{ml}$ of butanol and centrifuged at $1036 \times g$ for $10 \mathrm{~min}$. The absorbance was taken at $532 \mathrm{~nm}$ (Systronics 2202 UV-Vis Spectrophotometer). Trolox was used as antioxidant standard.

Inhibition of lipid peroxidation (\%) was calculated using the formula as given below:

$$
\text { Radical scavenging activity }(\%)=(1-\mathrm{E} / \mathrm{C}) \times 100
$$

where,

$\mathrm{C}$ is the absorbance of fully oxidized control,

$\mathrm{E}$ is the absorbance in the presence of test sample.
Ferric reducing antioxidant power (FRAP) assay

FRAP assay was carried out by the method of Benzie and Strain [57]. FRAP reagent was prepared by mixing acetate buffer, TPTZ solution and $\mathrm{FeCl}_{3} \cdot 6 \mathrm{H}_{2} \mathrm{O}$ solution in the ratio of 10:1:1. About $3 \mathrm{ml}$ of FRAP reagent was dispensed into the test tubes followed by addition of $300 \mu \mathrm{l}$ of test sample. Test tubes were shaken to mix the content well and incubated at $37{ }^{\circ} \mathrm{C}$ for $10 \mathrm{~min}$. Absorbance of the reaction mixture was taken at $593 \mathrm{~nm}$ (Systronics 2202 UV-Vis Spectrophotometer, India). Trolox was used as standard antioxidant. Increase in the absorbance of the reaction mixture as compared to control is considered as increase in the reducing potential of test sample.

\section{In vivo hepatoprotective activity Experimental animals}

All the in vivo work was done as per the guidelines of Committee for the Purpose of Control and Supervision of Experiments on Animals (CPCSEA), Ministry of Environment and Forests, Government of India for housing and experimentation on animals and the study was approved by the Institutional Animal Ethics Committee of Guru Nanak Dev University, Amritsar (226/CPCSEA/2014/08). Male Wistar rats weighing 240-280 g were used in this study and were procured from the animal house facility of Indian Institute of Integrative medicine (IIIM), Jammu (India). After the procurement, rats were kept in the polypropylene cages provided with paddy husk bedding. The temperature was maintained at $25 \pm 2{ }^{\circ} \mathrm{C}$ along with a $12 \mathrm{~h}$ light and $12 \mathrm{~h}$ dark cycle in the animal house of Guru Nanak Dev University, Amritsar (Punjab). All the animals were fed on standard pellet diet and water ad libitum and allowed to acclimatize for two weeks before the start of experimentation.

\section{Experimental design}

2-acetylaminofluorene (2-AAF) induced hepatic damage model was used to evaluate hepatotoxicity [58]. The animals were randomly divided into seven groups (Fig. 1), each containing four rats $(n=4)$. The experimental protocol was of total 15 days time period. Group I served as control group put on standard pellet diet. Group II served as vehicle control and animals received distilled water via oral route (1st to 15 th day) and corn oil injection intraperitoneally (i.p.) from 11th to 15th day. Group III served as positive control group was treated with 2-acetylaminofluorene (2-AAF) $(50 \mathrm{mg} / \mathrm{kg}$ bw; i.p.) for 5 consecutive days (11th to 15 th day). Group IV (Negative control) was treated with highest dose of plant extract alone (But-LI; $400 \mathrm{mg} / \mathrm{kg}$ bw) from day 1st to 15 th, Group V to VII were given 3 doses of plant extract $(100,200$ and $400 \mathrm{mg} / \mathrm{kg}$ bw from day 1 st to 15 th) 


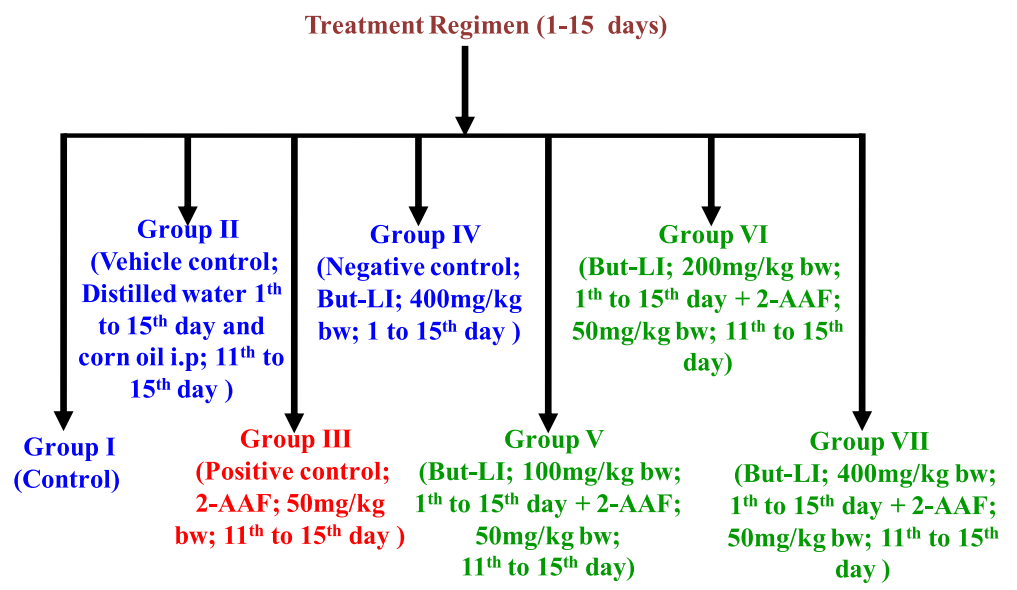

Fig. 1 Diagrammatic representation of treatment schedule

and toxicant 2-AAF $(50 \mathrm{mg} / \mathrm{kg}$ bw; intraperitoneally from day 11th to 15 th).

\section{Preparation of liver homogenate}

After completion of treatment period, all the rats were euthanized by cervical dislocation. Livers of the animals were perfused immediately in ice cold solution of $0.9 \%$ $\mathrm{NaCl}$. Livers were then made free from other kind of tissues and rinsed in chilled buffer $(0.15 \mathrm{M} \mathrm{KCl}+$ $10 \mathrm{mM}$ Tris-HCl, $\mathrm{pH}$ 7.4). After that livers were weighed immediately and finally homogenized in icecold Tris- $\mathrm{KCl}$ buffer to yield $10 \%(\mathrm{w} / \mathrm{v})$ homogenate using homogenizer.

\section{Biochemical analysis}

\section{Serum parameters}

Blood samples were taken using retro-orbital puncture after anesthetizing the rats. Briefly, blood was allowed to stand for sometime followed by centrifugation at $2400 \mathrm{rpm}$ for $20 \mathrm{~min}$. Clear supernatant so obtained was designated as serum. Various serum parameters viz. Serum glutamate oxaloacetate transaminase (SGOT), Serum glutamate pyruvate transaminase (SGPT) and Serum alkaline phosphatase (ALP) were measured on Autoanalyzer (Erba Mannheim XL-640) using kits (Erba Mannheim XL System Packs).

\section{Determination of lipid peroxidation}

Lipid peroxidation was determined in terms of the formation of thiobarbituric acid reactive species (TBARS) [59]. In order to measure TBARS, liver homogenate $(0.5 \mathrm{ml})$ was added to the TBA reagent $(20 \%$ TCA, $0.5 \%$ TBA, and $0.25 \mathrm{~N} \mathrm{HCl}$ ) in the test tubes. The contents of test tubes were mixed properly and heated at $80{ }^{\circ} \mathrm{C}$ for $30 \mathrm{~min}$. After the incubation, test tubes were cooled to room temperature and final absorbance was taken at
532 and $600 \mathrm{~nm}$. The amount of TBARS was expressed as MDA content ( $\mu$ mol MDA eq/g of tissue) from the calibration curve obtained using malondialdehyde (MDA) as standard compound.

\section{Histopathological studies}

For histopathological studies, liver tissues were fixed in $10 \%$ formalin solution. After that tissues were processed by routine histology method and finally embedded in paraffin wax. Tissue sections were then stained with haematoxylin and eosin stains. After the preparation of slides, the sections were studied for histopathological alterations under microscope equipped with camera. Coded histological samples of liver were scored for necroinflammatory score using the Ishak modified histological index grading [60].

\section{Statistical analysis}

The results were expressed as the average and standard error/standard deviation. $\mathrm{IC}_{50}$ values were calculated using regression equation. The data was analyzed for statistical significance using analysis of variance (Oneway ANOVA) and the difference among means was compared by HSD using Tukey's test. The significance of results was checked at ${ }^{*} p \leq 0.05$.

\section{Results}

In vitro antioxidant activity

In deoxyribose degradation assay, But-LI showed potent hydroxyl radical scavenging activity with percent inhibition of 31.81 at lowest tested concentration and $79.86 \%$ at highest tested concentration (Fig. 2). $\mathrm{IC}_{50}$ of $149.12 \mu \mathrm{g} / \mathrm{ml}$ was obtained from regression equation showed that fraction was more potent than standard rutin $\left(\mathrm{IC}_{50} 203.56 \mu \mathrm{g} / \mathrm{ml}\right)$. In lipid peroxidation inhibition assay, it showed moderate inhibition of $58.90 \%$ at 


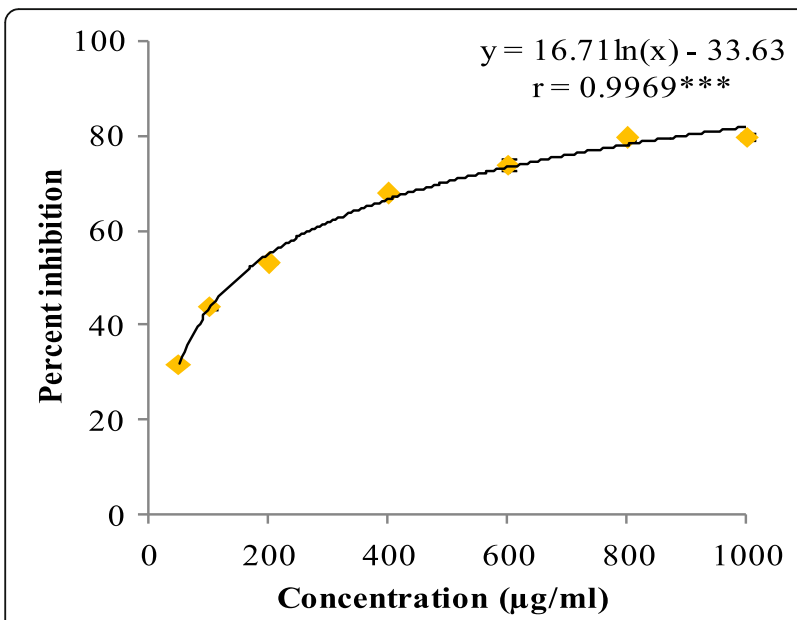

Fig. 2 Hydroxyl radical scavenging activity of But-LI from Lawsonia inermis leaves in Deoxyribose degradation assay. ${ }^{* * *}$ represents significance at $p \leq 0.001$

highest concentration and $39.33 \%$ at lowest concentration. But-LI showed higher $\mathrm{IC}_{50}(375.73 \mu \mathrm{g} / \mathrm{ml})$ than that of standard trolox $\left(\mathrm{IC}_{50} 136.47 \mu \mathrm{g} / \mathrm{ml}\right.$ ) (Fig. 3). But-LI displayed an absorbance of $0.72 \mathrm{~nm}$ in FRAP assay at highest tested concentration (Fig. 4). Standard compound trolox showed an increase in an absorbance of reaction mixture with $2.95 \mathrm{~nm}$ at same concentration $(200 \mu \mathrm{g} / \mathrm{ml})$. Results were dose-dependent as there was increase in absorbance with increase in the concentration of But-LI.

\section{In vivo hepatoprotective activity Serum parameters}

There was significant increase in the various serum toxicity markers viz. SGOT, SGPT and ALP on treatment with 2-AAF (Table 1). However, the vehicle control group and negative control group (But-LI treated)

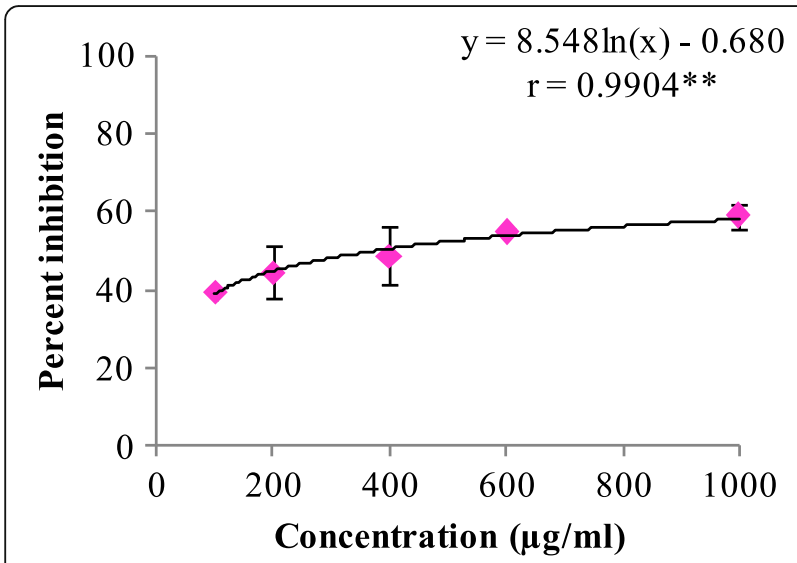

Fig. 3 Lipid peroxidation inhibitory activity of But-LI from Lawsonia inermis leaves in Lipid peroxidation inhibition assay. ${ }^{* *}$ represents significance at $p \leq 0.01$

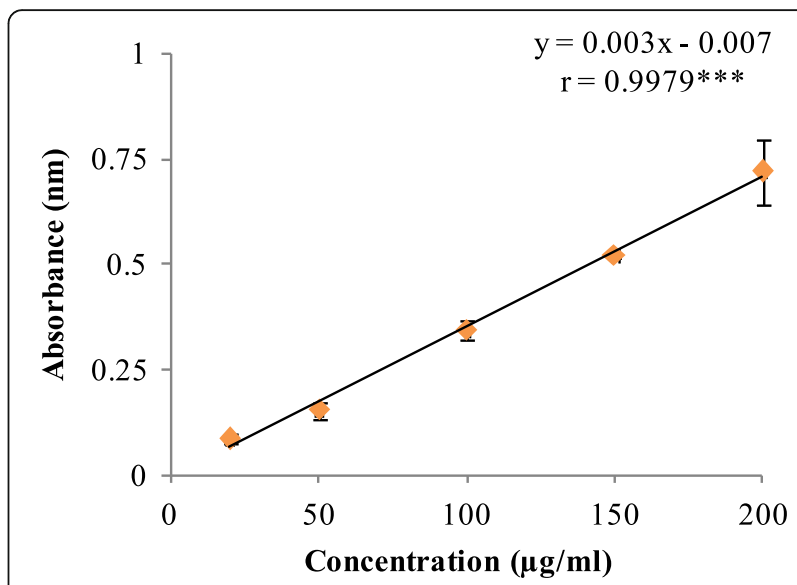

Fig. 4 Reducing potential of But-LI from Lawsonia inermis leaves in FRAP assay. ${ }^{* * *}$ represents significance at $p \leq 0.001$

showed values which were not statistical different to the normal control group at $p \leq 0.05$. The three different concentrations viz. $100 \mathrm{mg} / \mathrm{kg}, 200 \mathrm{mg} / \mathrm{kg}$ and $400 \mathrm{mg} / \mathrm{kg}$ bw of But-LI exhibited decrease in the values of these toxicity markers as compared to the toxicant i.e. 2-AAF treated group (Table 1).

\section{Determination of lipid peroxidation}

Normal control group (I), vehicle control group (II) and negative control group (IV) showed TBARS value of 17.69, 15.87 and $14.15 \mu \mathrm{mol} \mathrm{MDA}$ eq/g of tissue (Table 2). On the other hand, 2-AAF treated group (III) showed significant rise in the content of TBARS value of 52.07 $\mu \mathrm{mol} \mathrm{MDA} \mathrm{eq/g} \mathrm{of} \mathrm{tissue.} \mathrm{2-AAF} \mathrm{and} \mathrm{But-LI}$ co-treated groups (V, VI \& VII) showed dose dependent decrease in the TBARS values in comparison to 2-AAF treated group with value of $12.50 \mu \mathrm{mol} \mathrm{MDA} \mathrm{eq/g} \mathrm{of}$ tissue at the highest concentration of $400 \mathrm{mg} / \mathrm{kg} \mathrm{bw}$ (group VII) (Table 2).

\section{Histopathological studies}

Results showed that there was no damage to the liver in the normal control group (I), vehicle control group (II) and negative control group (IV) as the necroinflammatory score of these groups was zero. On the hand, histopathology examination of group III administered with 2-acetylaminofluorene (2-AAF) showed severe damage in the liver tissue with necroinflammatory score of 6/18. Group V, VI and VII administered with 100, 200 and $400 \mathrm{mg} / \mathrm{kg}$ bw of But-LI from L. inermis along with 2AAF showed noticeable protection against 2-AAF induced liver damage. The necroinflammatory score was found to be 1 at the highest tested concentration of But-LI (VII; $400 \mathrm{mg} / \mathrm{kg} \mathrm{bw}$ ) pointing towards its protective effects (Table 3 \& Fig. 5). Histopathological results revealed the 
Table 1 Effect of various treatments on hepatic parameters of male Wistar rats

\begin{tabular}{|c|c|c|c|c|}
\hline S. No. & Group & $\begin{array}{l}\text { SGOT } \\
(\mathrm{U} / \mathrm{L})\end{array}$ & $\begin{array}{l}\text { SGPT } \\
(\mathrm{U} / \mathrm{L})\end{array}$ & $\begin{array}{l}\text { ALP } \\
(\mathrm{U} / \mathrm{L})\end{array}$ \\
\hline 1. & Group I (Control) & $\mathrm{a}_{1} 14.00 \pm 11.284$ & ${ }^{a} 41.25 \pm 7.632$ & ${ }^{\mathrm{a}} 45.00 \pm 8.286$ \\
\hline 2. & Group II (Vehicle Control) & ${ }^{a} 138.25 \pm 6.652$ & ${ }^{\mathrm{a}} 41.00 \pm 1.414$ & ${ }^{a} 49.75 \pm 12.038$ \\
\hline 3. & Group III [(Positive control; 2-AAF (50 mg/kg body weight)] & ${ }^{b} 253.25 \pm 30.912$ & $b_{71.00 \pm 10.801}$ & ${ }^{b} 256.00 \pm 44.631$ \\
\hline 4. & Group IV (But-LI, 400 mg/kg body weight) & ${ }^{\mathrm{a}} 121.50 \pm 15.154$ & ${ }^{\mathrm{a}} 40.50 \pm 6.855$ & ${ }^{\mathrm{a}} 44.75 \pm 8.616$ \\
\hline 5. & Group V (2-AAF+ But-LI, 100 mg/kg body weight) & ${ }^{\mathrm{a}} 138.50 \pm 10.472$ & $\mathrm{a} 43.75 \pm 5.909$ & ${ }^{\mathrm{a}} 46.25 \pm 9.464$ \\
\hline 6. & Group VI (2-AAF+ But-LI, 200 mg/kg body weight) & ${ }^{\mathrm{a}} 129.25 \pm 10.242$ & ${ }^{\mathrm{a}} 49.00 \pm 9.931$ & ${ }^{\mathrm{a}} 38.75 \pm 4.500$ \\
\hline \multirow[t]{3}{*}{7.} & Group VII (2-AAF+ But-LI, 400 mg/kg body weight) & ${ }^{a} 118.50 \pm 11.618$ & 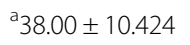 & $\mathrm{a}_{31.00 \pm 6.055}$ \\
\hline & F-ratio $(6,21)$ & $39.02^{*}$ & $7.80^{*}$ & $75.51^{*}$ \\
\hline & HSD & 35.91 & 18.76 & 42.82 \\
\hline
\end{tabular}

Means within the column followed by different superscripts letters are significantly different at ${ }^{*} p \leq 0.05$. Values expressed as Mean \pm SD

protective potential of But-LI and support the results obtained from the serum and lipid peroxidation parameters.

\section{Discussion}

Plant kingdom is regarded as gold repository of natural antioxidant constituents that can delay or prevent oxidation of other substances when ingested in daily diet [61]. During the last decade, bioprospection of phytoconstituents with nutritional and pharmaceutical importance is gaining popularity [62]. Numerous literature reports have demonstrated that medicinal plant extracts possess antioxidant and genoprotective activity [63-67]. Crude extracts or isolated molecules from medicinal plants not only possess antioxidant potential but they are even more potent than BHT, Vitamin E etc. in various in vitro experiments [68-70]. Mitochondrion is chief source of reactive oxygen species like superoxide anions $\left(\mathrm{O}_{2}{ }^{-}\right)$. Dismutation of superoxide anions radicals by superoxide dismutase enzyme leads to the formation of hydrogen peroxide $\left(\mathrm{H}_{2} \mathrm{O}_{2}\right)$. Hydrogen peroxide undergoes interaction with transition metal ions viz. $\mathrm{Fe}^{2+}$ or $\mathrm{Cu}^{+}$to

Table 2 Effect of various treatments on lipid peroxidation status of male Wistar rats

\begin{tabular}{|c|c|c|}
\hline \multirow[t]{2}{*}{ S. No. } & \multirow[t]{2}{*}{ Group } & \multirow{2}{*}{$\begin{array}{l}\text { Lipid peroxidatio } \\
\text { ( } \mu \text { mol MDA eq/ } \\
\text { of tissue) }\end{array}$} \\
\hline & & \\
\hline 1. & Group I (Control) & ${ }^{a} 17.69 \pm 3.460$ \\
\hline 2. & Group II (Vehicle Control) & ${ }^{\mathrm{a}} 15.87 \pm 3.591$ \\
\hline 3. & $\begin{array}{l}\text { Group III [(Positive control; 2-AAF } \\
\text { (50 mg/kg body weight)] }\end{array}$ & $b_{52.07 \pm 15.446}$ \\
\hline 4. & Group IV (But-LI, 400 mg/kg body weight) & ${ }^{a} 14.15 \pm 5.023$ \\
\hline 5. & Group V (2-AAF+ But-LI, 100 mg/kg body weight) & a $22.70 \pm 7.347$ \\
\hline 6. & Group VI (2-AAF+ But-LI, 200 mg/kg body weight) & ${ }^{\mathrm{a}} 16.33 \pm 3.967$ \\
\hline \multirow[t]{3}{*}{7.} & Group VII (2-AAF+ But-LI, 400 mg/kg body weight) & ${ }^{\mathrm{a}} 12.50 \pm 1.830$ \\
\hline & F-ratio $(6,21)$ & $14.753^{*}$ \\
\hline & HSD & 16.534 \\
\hline
\end{tabular}

Means within the column followed by different superscripts letters are significantly different at ${ }^{*} p \leq 0.05$. Values expressed as Mean \pm SD generate hydroxyl radicals $\left(\mathrm{OH}^{\circ}\right)$. Hydroxyl radicals $\left(\mathrm{OH}^{-}\right)$ cause number of harmful activities such as initiating lipid peroxidation and causing alterations in DNA [71]. But-LI showed statistically significant dose-dependent hydroxyl radical scavenging potential of $79.86 \%$ at highest tested concentration. Analysis of one way ANOVA showed F-ratio of 50.29 which was found to be statistically significant at $p \leq 0.05$. Regression analysis showed regression equation of $\mathrm{y}=16.71 \ln (\mathrm{x})-33.63 ; r=0.9969)$. The value of correlation coefficient was found to be significant at $p \leq 0.001$. Since the fraction contained numerous polyphenolic constituents in appreciable amount as reported in our earlier publication [51], the hydroxyl radical scavenging activity of the fraction might be attributed to these compounds. Similar results were reported by Thind et al. [72] who investigated root extracts of Schleichera oleosa for antioxidant activity using deoxyribose degradation assay and reported extracts as good hydroxyl radical scavengers. Kaur and Arora [73] evaluated antiradical potential of methanol extract of Chukrasia tabularis leaves using deoxyribose degradation assay and reported that extract possessed promising hydroxyl radical scavenging activity in deoxyribose degradation assay.

Reactive oxygen species are mainly generated in the mitochondria as byproduct of cellular metabolic processes and can affect biomolecules by causing damage [74]. Reactive intermediates resulting from oxidative stress can target membrane bilayers by causing lipid peroxidation. Polyunsaturated fatty acids in the membranes undergo lipid peroxidation resulting in lipoperoxyl radical (LOO) generation, which attack lipids to form lipid hydroperoxides $(\mathrm{LOOH})^{\circ}$ and lipid radicals. Lipid hydroperoxides are known to be unstable and can give rise to peroxyl and alkoxyl radicals and decompose to produce various secondary products. The breakdown products of lipid peroxides include malondialdehyde, hexanal, 4hydroxynonenal etc. which are highly reactive [75-78]. 4-hydroxynonenal is of electrophilic nature and reacts 
Table 3 Modified hepatic activity index (HAl) grading (necroinflammatory scores)

\begin{tabular}{|c|c|c|c|c|c|c|}
\hline S. No. & Group & $\begin{array}{l}\text { Periportal or } \\
\text { interface hepatitis } \\
\text { (Piecemeal necrosis) }\end{array}$ & Confluent necrosis & $\begin{array}{l}\text { Focal (spotty) lytic } \\
\text { necrosis, apoptotic } \\
\text { and focal inflammation }\end{array}$ & Portal inflammat-ion & Total score \\
\hline 1. & Group I & 0 & 0 & 0 & 0 & $0 / 18$ \\
\hline 2. & Group II & 0 & 0 & 0 & 0 & $0 / 18$ \\
\hline 3. & Group III & 2 & 1 & 1 & 2 & $6 / 18$ \\
\hline 4. & Group IV & 0 & 0 & 0 & 0 & $0 / 18$ \\
\hline 5. & Group V & 1 & 0 & 1 & 1 & $3 / 18$ \\
\hline 6. & Group VI & 0 & 0 & 0 & 1 & $1 / 18$ \\
\hline 7. & Group VII & 1 & 0 & 0 & 0 & $1 / 18$ \\
\hline
\end{tabular}

with glutathione, proteins and also with DNA at higher concentration $[79,80]$. In the present investigation, it was found that But-LI moderately inhibited the lipid peroxidation dose dependently $(\mathrm{y}=8.548 \ln (\mathrm{x})-0.680$; $r=0.9904)$. The value of correlation coefficient was found to be significant at $p \leq 0.01$. Earlier, we have reported that But-LI fraction harbours high amount of catechin, chlorogenic acid, ellagic acid and kaempferol while phytoconstituents such as gallic acid, epicatechin and quercetin were found to be present in moderate
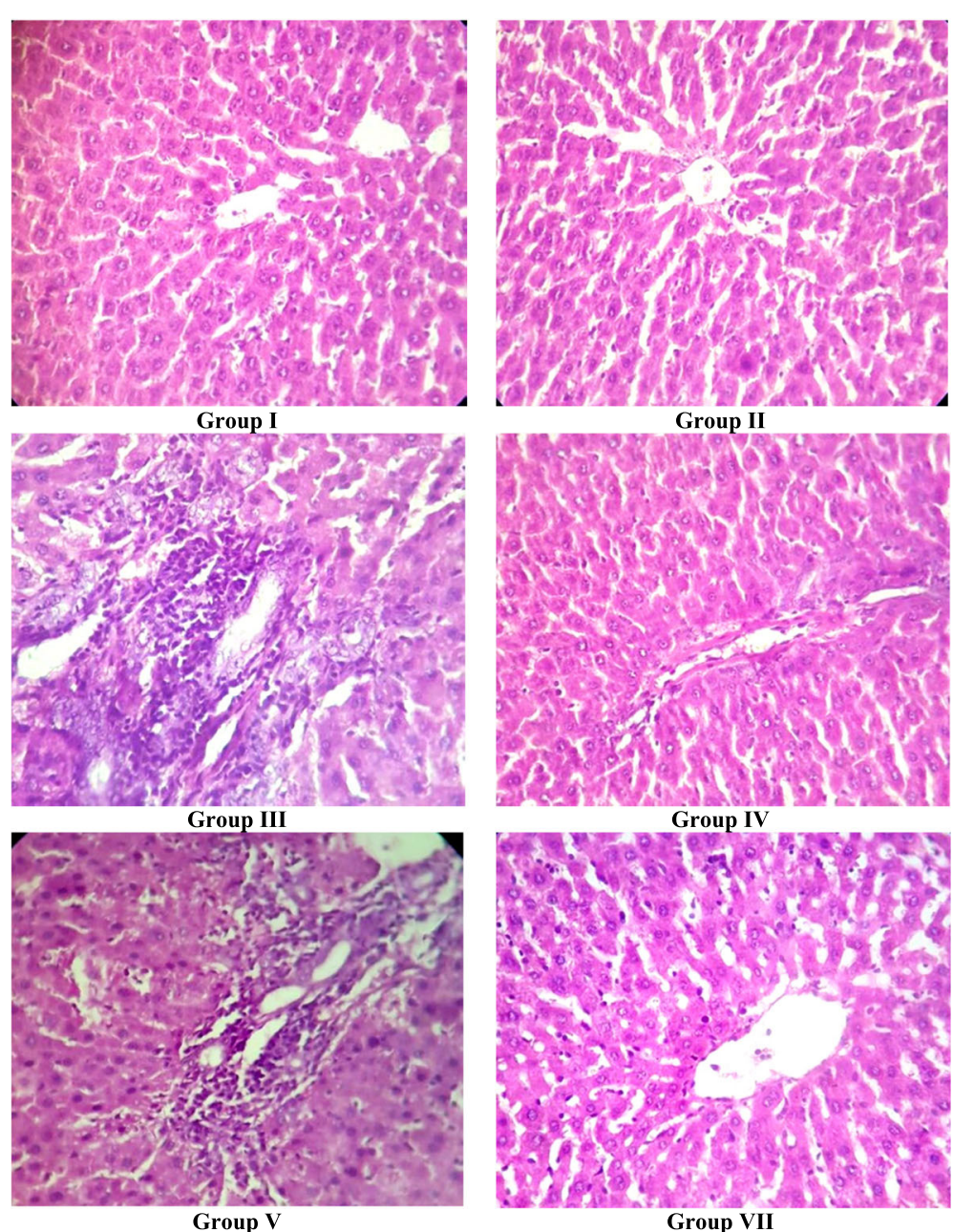

Fig. 5 Histopathological examination of liver sections of rats belonging to different groups. Group / (Control); Group I/ (Vehicle control); Group III [(Positive control; 2-AAF (50 mg/kg bw)]; Group N (But-LI, 400 mg/kg bw); Group V (2-AAF+ But-LI, 100 mg/kg bw); Group VII (2-AAF+ But-LI, 400 mg/kg bw) 
amount [51]. The lipid peroxidation inhibitory activity of the fraction might be due to various polyphenolic constituents present in it. Nakchat et al. [81] studied antioxidant activity including anti-lipid peroxidation activity of boiling water Tamarind seed coat extract and reported that extract effectively inhibited the lipid peroxidation. HPLC analysis of Tamarind seed coat extract showed presence of phenolics constitiuents such as (+)-catechin, (-)-epicatechin and procyanidin B2 which may be resposnsible for its antioxidant activities. Mulla and Swamy [82] studied antioxidant activity of polyphenolic extract of Portulaca quadrifida and reported that extract showed antilipid peroxidation activity of $71 \%$ with $\mathrm{IC}_{50}$ value of $370.33 \pm 2.91 \mu \mathrm{g} / \mathrm{ml}$. Results of FRAP assay revealed that But-LI fraction also possessed dosedependent reducing potential. Analysis of results using one way ANOVA showed F-ratio of 49.94 which was found to be statistically significant at $p \leq 0.05$. Regression analysis showed regression equation of $\mathrm{y}=0.003 \times-0.007$; $r=0.9979$. The value of correlation coefficient was found to be significant at $p \leq 0.001$. Reducing ability of the fraction may be due to polyphenols present in it. Singh et al. [83] studied leaf, fruit and seed extract of Moringa oleifera for antioxidant activity and reported that leaf extract possessed good reducing potential in reducing power assay. HPLC analysis of the extract demonstrated the presence of phenolic constituents such as gallic acid, chlorogenic acid, kaempferol, quercetin, ellagic acid, ferulic acid, and vanillin. Soobrattee et al. [84] studied various polphenolic phytochemicals for reducing potential in FRAP assay. Gallic acid, ellagic acid, chlorogenic acid, quercetin, kaempferol, (-)-epicatechin and (+)-catechin exhibited FRAP value of $5.25,4.39,3.22,7.39,1.95,2.90$ and $2.47 \mathrm{mmol} \mathrm{Fe}$ (II)/L respectively.

Several plant extracts and phytochemicals are reported to modulate the mammalian antioxidant enzymes system and provide protective effects against cellular damage [85-88]. Liver is the main organ responsible for detoxification processes occurring in the body. In the liver cells, endoplasmic reticulum is the primary site of metabolism. Hence, this metabolism is termed as hepatic metabolism. Besides liver, there are extrahepatic sites of metabolism which include organs such as lungs, kidney, skin, epithelial cells of gastrointestinal tract, adrenals and placenta [89-92]. Liver injury in response to various chemicals results in the leakage of serum enzymes into the blood circulation, thus causing increase in their level in the serum [93]. Sehrawat et al. [94] reported that 2-AAF administration to rats increased the level of SGOT and SGPT enzymes in serum. In another study, Hasan and Sultana [34] reported that 2-AAF treated rats demonstrated high level of serum aspartate aminotransferase (AST) and alanine aminotransferase (ALT). In the present investigation results obtained from serum toxicity markers such as SGOT, SGPT, ALP demonstrated significant increase on treatment with 2-AAF as compared to normal control. 2-AAF induced 2.22, 1.72 and 5.68 fold enhancements in SGOT, SGPT and ALP levels respectively. On co-administration of rats with 2-AAF and varying doses of But-LI, there was significant decrease in these serum parameters and the serum enzymes levels were restored towards normal control levels. The But-LI fraction alone did not induce any increase in the values of these markers and results were statistically not different to the normal control and vehicle control group at $p \leq 0.05$, reflecting non-toxic nature of But-LI fraction.

A study carried out by Selvanayaki and Ananthi [48] reported aqueous extract of Lawsonia inermis seeds with potent hepatoprotective effects against paracetamol induced hepatic damage in male rats. Extract significantly reduced the levels of various serum enzymes viz. aspartate aminotransferase (AST), acid phosphatase (ACP), alkaline aminotransferase (ALT), alkaline phosphatase (ALP) etc. altered by paracetamol treatment. Recently, Mohamed et al. [95] reported hepatoprotective potential of methanol extract of $L$. inermis leaves against carbon tetrachloride $\left(\mathrm{CCl}_{4}\right)$-induced hepatic damage. It was found that extract treatment significantly protected rats from hepatic damage induced by $\mathrm{CCl}_{4}$.

Lipid peroxidation is critical marker of oxidative stress and is coupled with various diseases including cancer [96, 97]. Malondialdehyde (MDA) and lipid hydroperoxides are produced as the result of lipid peroxidation of polyunsaturated fatty acids $[86,92]$. Results of the present investigation demonstrated that 2-AAF treatment resulted in 2.94 fold increase in the MDA level in rats. Further, treatment of rats with But-LI along with 2AAF reversed the effect of $2-\mathrm{AAF}$ as reflected from lower level of MDA. Our results are in agreement with previous studies [34, 88, 94, 95], in which natural plant products effectively reduced lipid peroxidation induced in response to various toxicants. Further, results of histopathological examination were also in concordance with results of other parameters and provided supportive evidence regarding protective potential of Lawsonia inermis (But-LI) fraction. It was found that 2-AAF administration to the male Wistar rats caused severe damage to the liver tissue, since it showed various histopathological alterations such as moderate piecemeal necrosis, mild confluent and spotty necrosis, moderate portal inflammation etc. with necroinflammatory score of 6 out of 18 . The untreated, vehicle and negative control group rats did not demonstrate such pathologies in their liver tissue and necroinflammatory score was found to be zero. All the 3 doses $(100,200$ and $400 \mathrm{mg} / \mathrm{kg}$ bw) provided protection against damage induced by 2 -AAF with necroinflammatory score of 1 out of 18 at highest tested dose $(400 \mathrm{mg} / \mathrm{kg} \mathrm{bw})$ and histoarchitecture 
of the animals in these groups was comparable to untreated control group. Hepatoprotection can be achieved either by reinstating the normal hepatic physiology or by diminishing the toxic damaging effect induced by toxicant [98]. The in vivo protective activity of But-LI of Lawsonia inermis against 2-AAF could be attributed to the various polyphenolic phytochemicals present in the fraction.

\section{Conclusions}

The present experimental findings revealed that phytoconstituents of Lawsonia inermis L. possess potential to protect rats from the 2-AAF induced hepatic damage in vivo possibly by inhibition of radicals and lipid peroxidation.

\section{Abbreviations}

2-AAF: 2-acetylaminofluorene; ALP: Alkaline phosphatase; CPCSEA: Committee for the purpose of control and supervision of experiments on animals; FRAP: Ferric reducing antioxidant power; MDA: Malondialdehyde; SGOT: Serum glutamic oxaloacetic transaminase; SGPT: Serum glutamic pyruvic transaminase; TBARS: Thiobarbituric acid reactive species; TPTZ: 2,4,6-tripyridyl-s-triazine

\section{Acknowledgements}

All the authors are thankful to the Department of Botanical and Environmental Sciences as well as Health Centre of Guru Nanak Dev University, Amritsar for providing necessary laboratory facilities to carry out this work

\section{Funding}

The authors are thankful to UGC (UPE \& CPEPA Programme) and PURSE programme of DST, New Delhi for providing financial assistance.

\section{Availability of data and materials}

All the data are included within the paper.

\section{Authors' contributions}

MK carried out major bioactivity part of present work. MK, PK, MC and APS collectively conducted antioxidant and hepatoprotective activities along with statistically analysis of the data. AJ helped in the histopathological studies. SK designed, supervised and critically checked the manuscript. All authors read and approved the final version of manuscript.

\section{Competing interests}

The authors declare that they have no competing interests.

\section{Consent for publication}

Not applicable.

\section{Ethics approval}

All the in vivo work was done as per the guidelines of Committee for the Purpose of Control and Supervision of Experiments on Animals (CPCSEA), Ministry of Environment and Forests, Government of India for housing and experimentation on animals and the study was approved by the Institutional Animal Ethics Committee of Guru Nanak Dev University, Amritsar (226/CPCSEA/2014/08)

\section{Author details}

'Department of Botanical and Environmental Sciences, Guru Nanak Dev University, Amritsar 143005, Punjab, India. ${ }^{2}$ Department of Pharmaceutical Sciences, Guru Nanak Dev University, Amritsar 143005, Punjab, India. ${ }^{3}$ Om Diagnostics, Amritsar, Punjab, India.

Received: 26 March 2016 Accepted: 7 January 2017

Published online: 18 January 2017

\section{References}

1. Thilly WG. Have environmental mutagens have caused oncomutations in people? Nat Genet. 2003;34:255-9.

2. Bertram JS. The molecular biology of cancer. Mol Aspects Med. 2001;21:167-223.

3. Miller JA, Miller EC. Metabolic activation and reactivity of chemical carcinogens. Mutat Res. 1975;33:25-6.

4. Boyland E. A chemist's view of cancer prevention. Proc R Soc Med. 1967:60:93-9.

5. Higginson J. Present trends in cancer epidemiology. Proc Can Cancer Conf. 1969:8:40-75.

6. Hemminki K, Sorsa M, Vainio H. Genetic risks caused by occupational chemicals. Use of experimental methods and occupational risk group monitoring in the detection of environmental chemicals causing mutations, cancer and malformations. Scand J Work Environ Health. 1979:5:307-27.

7. Doll R, Peto R. The causes of cancer: quantitative estimates of avoidable risks of cancer in the United States today. J Natl Cancer Inst. 1981:66:1191-308.

8. Mihailović V, Mihailović M, Uskoković A, Arambašić J, Mišić D, Stanković V, Katanić J, Mladenović M, Solujić S, Matić S. Hepatoprotective effects of Gentiana asclepiadea L. extracts against carbon tetrachloride induced liver injury in rats. Food Chem Toxicol. 2013:52:83-90.

9. Wolf PL. Biochemical diagnosis of liver diseases. Indian J Clin Biochem. 1999;14:59-90.

10. Lee CP, Shih PH, Hsu CL, Yen GC. Hepatoprotection of tea seed oil (Camellia oleifera Abel.) against $\mathrm{CCl}_{4}$-induced oxidative damage in rats. Food Chem Toxicol. 2007;45:888-95.

11. Jia XY, Zhang QA, Zhang ZQ, Wang Y, Yuan YF, Wang HY, Zhao D. Hepatoprotective effects of almond oil against carbon tetrachloride induced liver injury in rats. Food Chem. 2011;125:673-8.

12. Liu G, Liu X, Zhang Y, Zhang F, Wei T, Yang M, Wang K, Wang Y, Liu N, Cheng $\mathrm{H}$, Zhao $\mathrm{Z}$. Hepatoprotective effects of polysaccharides extracted from Zizyphus jujube cv. Huanghetanzao Int J Biol Macromol. 2015;76:169-75.

13. Qian Y, Ling CQ. Preventive effect of Ganfujian granule on experimental hepatocarcinoma in rats. World J Gastroenterol. 2004;10:1755-7.

14. Farazi PA, Depinho RA. Hepatocellular carcinoma pathogenesis: from genes to environment. Nat Rev Cancer. 2006:6:674-87.

15. Jemal A, Siegal R, Ward E, Murray T, Xu J, Thun MJ. Cancer statistics. CA Cancer J Clin. 2007:57:43-66.

16. Cengiz N, Kavak S, Guzel A, Ozbek H, Bektas H, Him A, Erdogan E, Balahoroglu R. Investigation of the hepatoprotective effects of Sesame (Sesamum indicum L.) in carbon tetrachloride-induced liver toxicity. J Membr Biol. 2013;246:1-6.

17. Hsu YW, Tsai CF, Chen WK, Lu FJ. Protective effects of seabuckthorn (Hippophae rhamnoides L.) seed oil against carbon tetrachloride-induced hepatotoxicity in mice. Food Chem Toxicol. 2009;47:2281-8.

18. Wilson RH, De Eds F, Cox Jr AJ. The toxicity and carcinogenic activity of 2-acetaminofluorene. Cancer Res. 1941:1:595-608.

19. Gonzalez FJ, Samore M, McQuiddy P, Kasper CB. Effects of 2acetylaminofluorene and $\mathrm{N}$-hydroxy-2-acetylaminofluorene on the cellular levels of epoxide hydratase, cytochrome P-450b, and NADPH-cytochrome (P-450) oxidoreductase messenger ribonucleic acids. J Biol Chem. 1982;257:11032-6.

20. Heflich RH, Neft RE. Genetic toxicity of 2-acetylaminofluorene, 2-aminofluorene and some of their metabolites and model metabolites. Mutat Res. 1994;318:73-114.

21. Verna L, Whysner J, Williams GM. 2-Acetylaminofluorene mechanistic data and risk assessment: DNA reactivity, enhanced cell proliferation and tumor initiation. Pharmacol Ther. 1996;71:83-105.

22. Lotlikar PD, Enomoto M, Miller JA, Miller EC. Species variations in the $\mathrm{N}$ - and ring-hydroxylation of 2-acetylaminofluorene and effects of 3-methylcholanthrene pretreatment. Proc Soc Exp Biol Med. 1967:125:341-6.

23. Miller EC. Some current perspectives on chemical carcinogenesis in humans and experimental animals: presidential address. Cancer Res. 1978;38:1479-96.

24. Strom SC, Jirtle RL, Michalopoulos G. Genotoxic effects of 2-acetylaminofluorene on rat and human hepatocytes. Environ Health Perspect. 1983;49:165-70.

25. Gupta M, Majumder UK, Thamilselvan V, Manikandan L, Senthilkumar GP, Suresh R, Kakotti BK. Potential hepatoprotective effect and antioxidant role of methanol extract of Oldenlandia umbellate in carbon tetrachloride induced hepatotoxicity in Wistar rats. Iranian J Pharmacol Ther. 2007;6:5-9. 
26. Prasad S, Kalra N, Shukla Y. Hepatoprotective effects of lupeol and mango pulp extract of carcinogen induced alteration in Swiss albino mice. Mol Nutr Food Res. 2007;51:352-9.

27. Opoku AR, Ndlovu IM, Terblanche SE, Hutchings AH. In vivo hepatoprotective effects of Rhoicissus tridentata subsp. cuneifolia, a traditional Zulu medicinal plant, against $\mathrm{CCl}_{4}$-induced acute liver injury in rats. S Afr J Bot. 2007;73:372-7.

28. Singh $H$, Bedi PS, Singh B. Hepatoprotective activity of turmeric and garlic against 7-12, dimethylbenzanthracene induced liver damage in Wistar albino rats. European J Med Plants. 2011;1:162-70.

29. Sharma N, Shukla S. Hepatoprotective potential of aqueous extract of Butea monosperma against $\mathrm{CCl}_{4}$ induced damage in rats. Exp Toxicol Pathol. 2011;63:671-6.

30. Akther N, Shawl AS, Sultana S, Chandan BK, Akhter M. Hepatoprotective activity of Marrubium vulgare against paracetamol induced toxicity. J Pharm Res. 2013:7:565-70.

31. Subramanian M, Balakrishnan S, Chinnaiyan SK, Sekar VK, Chandu AN. Hepatoprotective effect of leaves of Morinda tinctoria Roxb. against paracetamol induced liver damage in rats. Drug Invent Today. 2013;5:223-8.

32. Salama SM, Abdulla MA, Al Rashdi AS, Ismail S, Alkiyumi SS, Golbabapour S. Hepatoprotective effect of ethanolic extract of Curcuma longa on thioacetamide induced liver cirrhosis in rats. BMC Complement Altern Med. 2013;13:56.

33. Joshi BC, Prakash A, Kalia AN. Hepatoprotective potential of antioxidant potent fraction from Urtica dioica Linn. (whole plant) in $\mathrm{CCl}_{4}$ challenged rats. Toxicol Rep. 2015;2:1101-10.

34. Hasan SK, Sultana S. Geraniol attenuates 2- acetylaminofluorene induced oxidative stress, inflammation and apoptosis in the liver of Wistar rats. Toxicol Mech Methods. 2015;25:559-73.

35. Chopra RN, Nayer SL, Chopra IC. Glossary of India medicinal plants. New Delhi: CSIR Publications; 1956. p. 151.

36. Bellakhdar J. The traditional Moroccan pharmacopoeia: ancient Arabic medicine and popular knowledge. Paris: Ibis press; 1997.

37. Kumari P, Joshi GC, Tewari LM. Diversity and status of ethno-medicinal plants of Almora district in Uttarakhand. India Int J Biodivers Conserv. 2011;3:298-326.

38. Sharma J, Gairola S, Gaur RD, Painuli RM. The treatment of jaundice with medicinal plants in indigenous communities of the Sub-Himalayan region of Uttarakhand. India J Ethnopharmacol. 2012;143:262-91.

39. Oladunmoye MK, Kehinde FY. Ethnobotanical survey of medicinal plants used in treating viral infection among Yoruba tribes of South Western Nigeria. Afr J Microbiol Res. 2011:5:2991-3004.

40. Guha G, Rajkumar V, Ashok Kumar R, Mathew L. Antioxidant activity of Lawsonia inermis extracts inhibits chromium(VI)-induced cellular and DNA toxicity. Evid Based Complement Alternat Med. 2011. doi:10.1093/ecam/nep205.

41. Hsouna AB, Trigui M, Culioli G, Culioli G, Blache Y, Jaoua S. Antioxidant constituents from Lawsonia inermis leaves: isolation, structure elucidation and antioxidative capacity. Food Chem. 2010;125:193-200.

42. Raja W, Agrawal RC, Ovais M. Evaluation of antimutagenocity effect of Lawsonia inermis (henna) leaf extract in Swiss albino mice. Res J Pharm Technol. 2008;1:278-9.

43. Basirian M, Manjula SN, Mruthunjaya K. In vitro anti-clastogenic activity of different fractions of roots of Lawsonia inermis on chromosomal aberration of human lymphocytes against doxocirubicin and cyclophosphamide as clastogens. Int J Med Med Sci. 2013;46:1239-44.

44. Ali BH, Bashir AK, Tanira MO. Anti-inflammatory, antipyretic, and analgesic effects of Lawsonia inermis L. (henna) in rats. Pharmacology. 1995;51:356-63.

45. Mikhaeil BR, Badria FA, Maatooq GT, Amer M. Antioxidant and immunomodulatory constituents of henna leaves. Z Naturforsch C. 2004:59:468-76

46. Kaur M, Dangi CB, Singhai A, Singh M, Kosta S, Singh H, Peter J, Jain S. Toxicity profile of ethanolic extract of Lawsonia inermis leaves in albino Wistar rats. WJPPS. 2014:3:835-48

47. Alferah MAZ. Toxicity induced histological changes in selected organs of male (wistar) rats by Lawsonia inermis leaf extract. European J Med Plants. 2012;2:151-8.

48. Selvanayaki R, Ananthi T. Hepatoprotective activity of aqueous extract of Lawsonia inermis against paracetamol induced rats. Asian J Pharm Res. 2012;2:75-7.

49. Hossain CM, Maji HS, Chakraborty P. Hepatoprotective activity of Lawsonia inermis Linn, warm aqueous extract in carbon tetrachloride induced hepatic injury in Wister rats. Asian J Pharm Clin Res. 2011:4:106-9.
50. Dasgupta T, Rao AR, Yadava PK. Modulatory effect of Henna leaf (Lawsonia inermis) on drug metabolising phase I and phase II enzymes, antioxidant enzymes, lipid peroxidation and chemically induced skin and forestomach papillomagenesis in mice. Mol Cell Biochem. 2003;245:11-22.

51. Kumar M, Kumar S, Kaur SJ. Identification of polyphenols in leaf extracts of Lawsonia inermis L. with antioxidant, antigenotoxic and antiproliferative potential. Int J Green Pharm. 2014;8:23-36.

52. Kumar M, Kaur P, Kumar S, Kaur S. Antiproliferative and apoptosis inducing effects of non-polar fractions from Lawsonia inermis L. in cervical (HeLa) cancer cells. Physiol Mol Biol Plants. 2015;21:249-60.

53. Halliwell B, Gutteridge JMC, Aruoma OI. The deoxyribose method: a simple "test-tube" assay for determination of rate constants for reaction of hydroxyl groups. Anal Biochem. 1987;165:215-9.

54. Aruoma OI, Grootveld M, Halliwell B. The role of iron in ascorbatedependent deoxyribose degradation. Evidence consistent with a site specific hydroxyl radical feneration caused by iron ions bound to the deoxyribose molecule. J Inorg Biochem. 1987;29:289-99.

55. Ohkowa M, Ohisi N, Yagi K. Assay for lipid peroxides in animal tissue by thiobarbituric acid reaction. Anal Biochem. 1979;95:351-8.

56. Ruberto G, Baratta MT, Deans SG, Dorman HJD. Antioxidant and antimicrobial activity of Foeniculum vulgare and Crithmum maritimum essential oils. Planta Med. 2000;66:687-93.

57. Benzie IFF, Strain JJ. The ferric reducing ability of plasma as a measure of 'antioxidant power': the FRAP assay. Anal Biochem. 1996;239:70-6.

58. Hasan SK, Khan R, Ali N, Khan AQ, Rehman MU, Tahir M, Lateef A, Nafees S, Mehdi SJ, Rashid S, Shahid A, Sultana S. 18- $\beta$ Glycyrrhetinic acid alleviates 2-acetylaminofluorene-induced hepatotoxicity in Wistar rats: role in hyperproliferation, inflammation and oxidative stress. Hum Exp Toxicol. 2015:34:628-41.

59. Devasagayam TPA, Boloor KK, Ramasarma T. Methods for estimating lipid peroxidation: ananalysis of merits and demerits. Indian J Biochem Biophys. 2003;40:300-8.

60. Ishak K, Baptista A, Bianchi L, Callea F, De Groote J, Gudat F, Denk H, Desmet V, Korb G, MacSween RNM, Phillips MJ, Portmann BG, Paulsen H, Scheuer PJ, Schmid M, Thaler $\mathrm{H}$. Histological grading and staging of chronic hepatitis. J Hepatol. 1995;22:696-9.

61. Girgih AT, He R, Hasan FM, Udenigwe CC, Gill TA, Aluko RE. Evaluation of the in vitro antioxidant properties of a cod (Gadus morhua) protein hydrolysate and peptide fractions. Food Chem. 2015;173:652-9.

62. Wangensteen $H$, Samuelsen $A B$, Malterud KE. Antioxidant activity in extracts from coriander. Food Chem. 2004;88:293-7.

63. Giao MS, González-Sanjosé ML, Rivero-Pérez MD, Pereira Cl, Pintado ME, Malcata FX. Infusions of Portuguese medicinal plants: dependence of final antioxidant capacity and phenol content on extraction features. J Sci Food Agric. 2007:87:2638-47.

64. Giao MS, Pereira Cl, Fonseca SC, Pintado ME, Malcata FX. Effect of particle size upon the extent of extraction of antioxidant power from the plants Agrimonia eupatoria, Salvia sp. and Satureja montana. Food Chem. 2009;117:412-6.

65. Kumar M, Kumar S, Kaur SJ. Investigations on DNA protective and antioxidant potential of chloroform and ethyl acetate fractions of Koelreuteria paniculata Laxm. Afr J Pharm Pharmacol. 2011:5:421-7.

66. Chandel M, Sharma U, Kumar N, Singh B, Kaur S. Antioxidant activity and identification of bioactive compounds from leaves of Anthocephalus cadamba by ultra-performance liquid chromatography/electrospray ionization quadrupole time of flight mass spectrometry. Asian Pac J Trop Med. 2012;5:977-85.

67. Kaur $\mathrm{P}$, Kaur $\mathrm{V}$, Kumar M, Kaur S. Suppression of SOS response in E. coli PQ 37, antioxidant potential and antiproliferative action of methanolic extract of Pteris vittata L. on human MCF-7 breast cancer cells. Food Chem Toxicol. 2014;74:326-33.

68. Gordon MH, Weng XC. Antioxidant properties of extracts from tanshen (Salvia miltiorrhiza Bunge). Food Chem. 1992;44:119-22.

69. Gu LW, Weng XC. Antioxidant activity and components of Salvia plebeia R. Br. - a Chinese herb. Food Chem. 2001;73:299-305.

70. Pyo YH, Lee TC, Logendrac L, Rosen RT. Antioxidant activity and phenolics compounds of Swiss chard (Beta vulgaris subspecies cycla) extracts. Food Chem. 2004:85:19-26.

71. Halliwell B, Gutteridge JMC. Free radicals in biology and medicine. Oxford, New York: Oxford University Press; 1999. 
72. Thind TS, Singh R, Kaur R, Rampal G, Arora S. In vitro antiradical properties and total phenolic contents in methanol extract/fractions from bark of Schleichera oleosa (Lour.) Oken. Med Chem Res. 2011;20:254-60.

73. Kaur R, Arora S. Investigations of antioxidant activity of methanol extract of Chukrasia tabularis. A Juss J Chin Clin Med. 2008:3:200-5.

74. Riess ML, Camara AKS, Kevin LG, An J, Stowe DF. Reduced reactive $\mathrm{O}_{2}$ species formation and preserved mitochondrial $\mathrm{NADH}$ and $\left[\mathrm{Ca}^{2+}\right]$ levels during short-term $17^{\circ} \mathrm{C}$ ischemia in intact hearts. Cardiovas Res. 2004;61:580-90

75. Halliwell B, Chirico S, Crawford MA, Bjerve KS, Gey KF. Lipid peroxidation: its mechanism, measurement, and significance. Am J Clin Nutr. 1993;57:715S-24.

76. Gardner HW. Oxygen radical chemistry of polyunsaturated fatty acids. Free Radic Biol Med. 1989;7:65-86.

77. Spiteller P, Kern W, Reiner J, Spiteller G. Aldehydic lipid peroxidation products derived from linoleic acid. Biochim Biophys Acta. 2001;1531:188-208.

78. Barrera G, Pizzimenti S, Dianzani MU. Lipid peroxidation: control of cell proliferation, cell differentiation and cell death. Mol Aspects Med. 2008;29:1-8.

79. Esterbauer $\mathrm{H}$, Schaur RJ, Zollner $\mathrm{H}$. Chemistry and biochemistry of 4hydroxynonenal, malonaldehyde and related aldehydes. Free Radic Biol Med. 1991;11:81-128.

80. Uchida K. 4-Hydroxy-2-nonenal: a product and mediator of oxidative stress. Prog Lipid Res. 2003:42:318-43.

81. Nakchat O, Meksuriyen D, Pongsamart S. Antioxidant and anti-lipid peroxidation activities of Tamarindus indica seed coat in human fibroblast cells. Indian J Exp Biol. 2014;52:125-32.

82. Mulla SK, Swamy P. Antioxidant activity of ethanolic and polyphenolic extracts of Portulaca quadrifida. Int J Biol Pharm Res. 2012:3:392-9.

83. Singh BN, Singh BR, Singh RL, Prakash D, Dhakarey R, Upadhyay G, Singh HB. Oxidative DNA damage protective activity, antioxidant and anti-quorum sensing potentials of Moringa oleifera. Food Chem Toxicol. 2009;47:1109-16.

84. Soobrattee MA, Neergheen VS, Luximon-Ramma A, Aruoma Ol, Bahorun T. Phenolics as potential antioxidant therapeutic agents: mechanism and actions. Mutat Res. 2005;579:200-13.

85. Yener Z, Celik I, Ilhan F, Bal R. Effects of Urtica dioica L. seed on lipid peroxidation, antioxidants and liver pathology in aflatoxin-induced tissue injury in rats. Food Chem Toxicol. 2009;47:418-24.

86. Ansil PN, Nitha A, Prabha SP, Wills PJ, Jazaira V, Latha MS. Protective effect of Amorphophallus campanulatus (Roxb.) Blume. tuber against thioacetamide induced oxidative stress in rats. Asian Pac J Trop Med. 2011;4:870-7.

87. Xia DZ, Zhang PH, Fu Y, Yu WF, Ju MT. Hepatoprotective activity of puerarin against carbon tetrachloride-induced injuries in rats: a randomized controlled trial. Food Chem Toxicol. 2013;59:90-5.

88. Kaur R, Arora S. Interactions of betulinic acid with xenobiotic metabolizing and antioxidative enzymes in DMBA-treated Sprague Dawley female rats. Free Radic Biol Med. 2013:65:131-42.

89. Plant N. Molecular Toxicology. New York: Bios Scientific Publishers; 2003.

90. Coleman M. Human drug metabolism: an introduction. 1st ed. UK: John Wiley \& Sons; 2010. p. 13-8.

91. Iyanagi T. Molecular mechanism of phase I and phase II drug-metabolizing enzymes: implications for detoxification. Int Rev Cytol. 2007;260:35-112.

92. Taxak N, Bharatam PV. Drug metabolism. A fascinating link between chemistry and biology. Resonance. 2014;19:259-82.

93. Drotman R, Lawhan G. Serum enzymes are indications of chemical induced liver damage. Drug Chem Toxicol. 1978;1:163-71.

94. Sehrawat A, Sharma S, Sultana S. Preventive effect of tannic acid on 2-acetylaminofluorene induced antioxidant level, tumor promotion and hepatotoxicity: a chemopreventive study. Redox Rep. 2006;11:85-95

95. Mohamed MA, Eldin IM, Mohammed AE, Hassan HM. Effects of Lawsonia inermis L. (Henna) leaves methanolic extract on carbon tetrachlorideinduced hepatotoxicity in rats. J Intercult Ethnopharmacol. 2015:5:22-6.

96. Gerber M, Astre C, Segala C, Saintot M, Scali J, Simony-Lafontaine J, Grenier J, Pujol H. Tumor progression and oxidant-antioxidant status. Cancer Lett. 1997;114:211-4.

97. Saintot M, Astre C, Pujol H, Gerber M. Tumor progression and oxidantantioxidant status. Carcinogenesis. 1996;17:1267-71.

98. Verma VK, Sarwa KK, Kumar A, Zaman MDK. Comparison of hepatoprotective activity of Swertia chirayita and Andrographis paniculata plant of North East India against $\mathrm{CCl}_{4}$ induced hepatotoxic rats. J Pharm Res. 2013;7:647-53.

\section{Submit your next manuscript to BioMed Central and we will help you at every step:}

- We accept pre-submission inquiries

- Our selector tool helps you to find the most relevant journal

- We provide round the clock customer support

- Convenient online submission

- Thorough peer review

- Inclusion in PubMed and all major indexing services

- Maximum visibility for your research

Submit your manuscript at www.biomedcentral.com/submit
Biomed Central 